\title{
EFFECT OF RECOMBINANT BOVINE SOMATOROPIN (rbST) ON SEMEN PHYSICAL CHARACTERISTICS AND SOME BIOCHEMICAL CONSTITUENTS IN SEMINAL PLASMA OF FRIESIAN BULLS
}

\author{
Y. M. Hafez ${ }^{1}$, Soheir A. Fawzy ${ }^{2}$, M. A. El-Henawy ${ }^{2}$ and A. H. Barkawi ${ }^{1}$ \\ 1- Animal Production Department, Faculty of Agriculture, Cairo University, Giza, \\ Egypt, 2- Animal Production Research Institute, Ministry of Agriculture, Dokki, \\ Giza, Egypt
}

\section{SUMMARY}

To investigate the effects of recombinant bovine somaotropin (rbST) on semen quality and some parameters in seminal plasma of bulls, six Friesian bulls (17.5 to 21.5 month old) were divided into two groups each of three bulls. One group was injected with a dose of $500 \mathrm{mg}$ of rbST every 14 days for eight injections, while the other group received saline soluation $0.9 \% \mathrm{NaCl}$ in similar regim. Two successive semen ejaculates were collected twice weekly for 16 weeks (no= 192 ejaculates), to determine the physical caracteristics, in addition to intial fructose and methylene blue reduction test. Field results of conception rate were used as an additional overall criterion of semen quality.

The obatined results revealed that rbST injection improved semen quality. Ejaculate volume was inceased by $29 \%$ and mass motility was active by $34.6 \%$, in case of rbST treated bulls. The precentage of abonormal sperm was decreased by $25 \%$ and sperm cell concentration was increased by $44 \%$ in rbST treated bulls and so increased the total number of spermatoza in ejaculates by $87 \%$. Concentrations of AST and ALT enzymes in seminal plasma were higher in rbST treated bulls by 15.3 and $15.9 \%$, respectively. Semen of rbST treated bulls had lower methylene blue reduction time (10.5 vs. $20.9 \mathrm{~min})$, higher intitial fructose (411.6 vs. 298.8mg/100) and higher conception rate (64 vs. 36 5\%). Bulls treated with rbST had higher $(P<0.05)$ plasma testosterone $(61 \%)$, which seems to parallel to improve semen quality.

The present results indicate a possible beneficial use of exogenous rbST for improving bulls semen quality.

Keywords: rbST, Friesian bulls, semen quality, seminal plasma constituents

\section{INTRODUCTION}

The importance of growth hormone $(\mathrm{GH})$ for male reproductive function has initially been deduced from the observation that in humans with isolated $\mathrm{GH}$ deficiency, puberty is delayed and can be normalized by GH treatment (Laron, 1984). Studies in rodents had further substantiated the necessity of GH for normal spermatogenesis (Arsenijevic et al., 1989) and the development of male reproductive function (Sptiteri-Grech and Nieschlag, 1990).

Issued by The Egyptian Society of Animal Production 
A potential benefit of $\mathrm{GH}$ treatment on semen characteristic has been reported from GH- deficient individuals (Radicioni et al., 1994 and Ovesen et al., 1996). The effects of rbST on reproductive efficiency of Friesian bulls might be explained by investigating the endocrine status and metabolites concentration in blood and seminal plasma. Also, field measures such as non return rate of inseminated cows is one of the best measures to assess the quality of semen produced by rbST treated bulls.

The objective of this study was to examine the potency of rbST in improving seminal quality in Friesian bulls and its impact on plasma testosterone concentration.

\section{MATERIALS AND METHODS}

This study was conducted at Sakha Research Station, Kafr El-Sheikh Governorte, Animal Production Research Institute, Ministry of Agriculture during the period from September 2000 to January 2001.

\section{Animals}

Six young Friesian bulls aged 17.5 to 21.5 months old with an average live body weight of $295 \mathrm{~kg}$ were used in this study. Body weight and age of experimental bulls in control and rbST groups were nearly similar averaging $301.7 \pm 6.01 \mathrm{Kg}, 288.3 \pm 8.02$ $\mathrm{Kg}$ and $17.8 \pm 0.71$ months, $19.3 \pm 1.01$ months, respectively. Feed was formulated based on NRC allowances (NRC, 1988) and water was offered twice daily. Semen was collected from each bull twice weekly, in two consecutive ejaculates by means of artificial vagina. This routine of semen collection was continued throughout the experimental period (Septembre to January). Animals were randomly allocated to receive a subcutaneously injection of either saline solution $(1.0 \mathrm{ml})$ as control or rbST (Somatech ${ }^{\circledR}$, Elcano, USA), $500 \mathrm{mg}$ per dose in the same voulme of saline every14 days for eight injections. Bulls of the two groups were kept under similar managerial conditions.

\section{Blood sampling}

Blood samples were collected from Jugular vein in heparinized tubes once weekly (at 8 a.m.) throughout the experimental period. The blood samples were centrifuged for $20 \mathrm{~min}$ at $3000 \mathrm{rpm}$ for plasma separation, which kept at $-20^{\circ} \mathrm{C}$ until analyzed.

\section{Semen sampling}

The semen ejaculates were evaluated with regard to volume (measured by a graduated collecting tube to the nearest $0.1 \mathrm{ml}$ ), mass motility of spermatozoa (checked by microscopic evaluation as a score ranging from 0 to 5, Perry, 1960). Live sperm (\%) evaluation and the morphological examinations of spermatozoa in fresh ejaculate were performed according to Hancock (1951 \& 1956). Semen density was determined using spectrophotometer SDM4. Total sperm output for each ejaculate was calculated according to following formula:

Total sperm output/ejaculate $\left(\mathrm{x} 10^{9}\right)=$ semen volume $\mathrm{x}$ sperm concentration $/ \mathrm{ml}$.

Methylene blue reduction time was estimated according to the method adopted by Herman and Madden (1953).

\section{Conception rate}

The seminal ejaculate was divided into two halves; one half for artificial insemination purposes which was diluted by egg yolk sodium citrate extender to 
$20 \times 10^{6}$ spermatozoa per $0.25 \mathrm{ml}$, aliquated in straws, frozen and stored in liquid nitrogen. The other half was frozen at $-20^{\circ} \mathrm{C}$ for biochemical assay. The fertility of the semen samples was obtained from the results of pregnancy diagnosis through rectal palpation two months after the first service using 50 clinically normal cows from the same farm ( 25 cows per group). All cows received one insemination by the same inseminator.

\section{Seminal plasma assays}

\subsection{Fructose concentration $(\mathrm{mg} / 100 \mathrm{ml})$}

Initial fructose concentration was determined calorimetrically throughout the experimental period in seminal plasma according the method of Mann (1964).

\subsection{Asparate aminotransferase (AST) and Alanine aminotransferas (ALT) concentration in seminal plasma}

The concentration of AST and ALT (RFU/ ml) were determined colorimetrically in seminal plasma according to the method described by Retiman and Frankel (1957). Results were expressed as Retiman-Frankel units (R.F.U/ ml).

\section{Blood plasma testosterone concentration $(\mathrm{ng} / \mathrm{ml})$}

Assessment of plasma testosterone concentration was performed using a single antibody radioimmunoassay (RIA) technique (DSL- 4000 kits, USA). According to the manifacturer information, the sensitivity of the test was reported to be $0.08 \mathrm{ng} / \mathrm{ml}$. The cross reactivites of the testosterone antiserum are 5.8, 4.2 and $2.3 \%$ for $5 \alpha$ dihydrotestosterone, 11-oxotestosterone and androstene-dione, respectively. The intra and inter assay coefficients of variability was $8.1 \%$ and $9.1 \%$, respectively.

\section{7-Statistical analysis}

Data were analysed using the general linear model of SAS (1998) using the following model:

$$
\mathrm{Y}_{\mathrm{ij}}=\mathrm{u}+\mathrm{T}_{\mathrm{I}}+\mathrm{E}_{\mathrm{ij}} \text {, where: }
$$

Yij= The observation $\mathrm{ij}$

$\mathrm{u}=$ overall mean

$\mathrm{Ti}=$ treatment $(1$ for contol and 2 for treatment)

Eij= Experimental error associated with $i^{\text {th }}$ and $j^{\text {th }}$ observations assumed to be randamlly distributed.

\section{RESULTS AND DISCUSSION}

\section{Semen physical characteristics}

All physical characteristics of Friesian semen improved $(\mathrm{P}<0.05)$ by $\mathrm{rbST}$ treatment (Table 1). This trend is in agreement with the findings of EL-Harairy (2000) who reported an increase $(\mathrm{P}<0.05)$ of semen ejaculate volume, percentage of live sperm and total sperm output and decrease $(\mathrm{P}<0.05)$ of abnormal spermatozoa in mature rams treated by $100 \mathrm{mg}$ rbST every 14 days for five injections. The decrease $(\mathrm{P}<0.05)$ of sperm abnormalities percentage and the increase of sperm output in bulls treated with rbST are in accordance with those of Sauerwein et al. (2000) on Simmental sires treated with $640 \mathrm{mg}$ rbST every 14 days for 7 injections, this 
treatment decreased percentage of deformed spermatozoa by $15.3 \%$ and increased sperm cell concentratiom by $30 \%$.

Table 1. Semen physical characteristics (Means \pm S.D) as affected by $\operatorname{rbST}$ treatment

\begin{tabular}{lcc}
\hline Parameters & Control group & rbST group \\
\hline Ejaculate volume (ml) & $3.1^{\mathrm{a}} \pm 0.77$ & $4.0^{\mathrm{b}} \pm 1.19$ \\
Mass motility (score; 0-5) & $2.6^{\mathrm{a}} \pm 0.64$ & $3.5^{\mathrm{b}} \pm 0.67$ \\
Live sperm (\%) & $69.1^{\mathrm{a}} \pm 10.68$ & $77.2^{\mathrm{b}} \pm 8.62$ \\
Abnormal sperm (\%) & $22.5^{\mathrm{a}} \pm 4.22$ & $16.8^{\mathrm{b}} \pm 5.83$ \\
Sperm concentration $\left(\mathrm{x} 10^{9} / \mathrm{ml}\right)$ & $0.890^{\mathrm{a}} \pm 0.437$ & $1.287^{\mathrm{b}} \pm 0.464$ \\
Sperm output $\left(\mathrm{x} 10^{9} /\right.$ ejaculate $)$ & $2.926^{\mathrm{a}} \pm 1.941$ & $5.484^{\mathrm{b}} \pm 3.060$ \\
\hline Means within the same row having different superscripts differ significantly at $5 \%$.
\end{tabular}

\section{Seminal plasma constituents}

It is clear from the present results (Table 2) that the reduction of methylen blue was faster in semen collected from rbST treated bulls than control ones by 10 minutes (10.5 vs 20.9 min, respectively). Moreover, the treatment with rbST resulted in an increase $(\mathrm{P}<0.05)$ in fructose and AST and ALT concentrations in seminal plasma. Hignett (1957) stated that methylen blue reduction time was less than 15 minutes in case of good semen samples in mature Friesian bulls.

Table 2. Relevant seminal plasma constituents concentrations (Means+SD) as affected by rbST treatment

\begin{tabular}{lcc}
\hline Parameters & Control group & rbST group \\
\hline Methylene blue reduction time (min.) & $20.94^{\mathrm{b}} \pm 16.67$ & $11.55^{\mathrm{a}} \pm 7.76$ \\
Fructose (mg/100) & $289.8^{\mathrm{b}} \pm 79.9$ & $411.6^{\mathrm{a}} \pm 121.8$ \\
Asparate aminotransferase (RFU/ml) & $99.0^{\mathrm{b}} \pm 28.5$ & $114.1^{\mathrm{a}} \pm 27.9$ \\
Alanine aminotransferas (RFU/ml) & $28.9^{\mathrm{b}} \pm 9.5$ & $33.5^{\mathrm{a}} \pm 11.6$ \\
\hline
\end{tabular}

Means within the same row having different superscripts differ significantly at $5 \%$.

\section{Blood plasma testosterone}

Bulls treated with rbST had higher $(\mathrm{P}<0.05)$ plasma testosterone concentration compared to control group averaging $2.9 \pm 2.5$ and $1.8 \pm 1.3 \mathrm{ng} / \mathrm{ml}$, respectively. This result agrees with El- Harairy (2000), reporting higher blood plasma testosterone concentration in rams treated with rbST compared to the untreated rams (2.65 vs 2.52 $\mathrm{ng} / \mathrm{ml})$.

\section{Conception rate}

As shown in figure (1) conception rate was higher $(64 \%)$ in rbST treated sires compared to the control one $(36 \%)$. This may be due to the effect of rbST in improving semen characteristics (Table 1). This is in agreement with the findings of, Sauerwein et al. (2000) who reported that rbST treatment had improved fertilization rates $(66.8$ to $73.2 \%)$ of breeding bulls used for artificial insemination. 


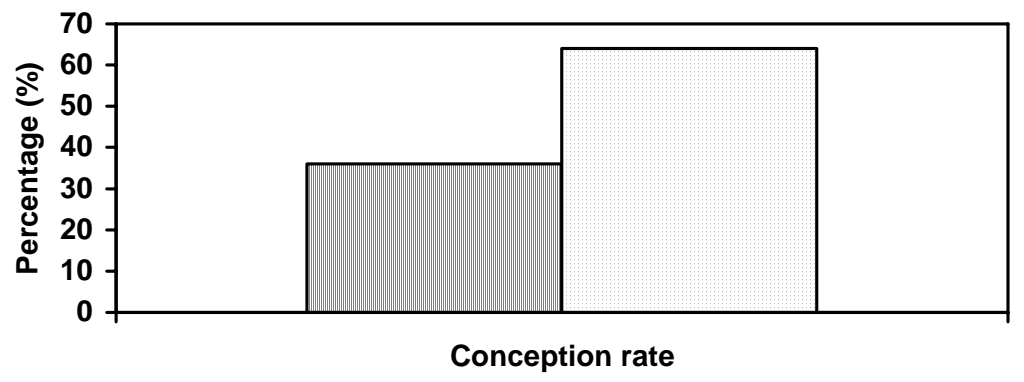

$\square$ Control $\square$ rbST

Fig. 1. Conception rate (from the first insemination) using frozen semen collected from treated (rbST) or untreated (control) Friesian bulls

\section{GENERAL DISCUSSION}

The present results indicated that treatment with rbST improved significantly the physical characteristics of semen of Friesian bulls (Table 1). This is most probably attributed to the effect of rbST on Leydig cell function (Carani et al., 1999) via increase of LH secretion (Sauerwein et al., 2000 and Chandrasheker and Barttke, 1998). The increase of LH might cause the observed increase of testosterone concentration in treated bulls which is in accordance with the findings of Sauerwein et al. (2000).

Besides the alteration of testosterone, rbST act directly on the spermatogenic surface of the testicular tubules or indirectly by elevating IGF-1 plasma concentration (Sauerwein et al., 2000). The present findings are supported by the results of Lee et al. (1995) and Breier et al. (1998) in men and Schallenberger et al. (1993) and Sauerwein et al. (2000) in bovine indicating that poor semen quality could be restored by treatment with growth hormone. Henault et al. (1995) showed that the mode of action of growth hormone on fertilization efficiency is by improving the components of the ejaculate and increase of fructose $(\mathrm{mg} / 100 \mathrm{ml})$ concentration in treated sires (Sauerwein et al., 2000). The increase of AST and ALT concentration in seminal plasma was positively correlated with live sperm percentage (Roussel and Stallcup, 1966). Also, Pareek et al. (1981) clamied that AST release was positively correlated with ram sperm motility. There is substantial evidence that growth hormone does affect testicular function by modulating gonadal steroid synthesis and gametogenesis (Zachman, 1992).

Moreover, injection of rbST in bulls causes a kind of nutrient partitioning to improve the semen quality of the bulls (Sauerwein et al., 2000). 
In conclusion, injection of $\mathrm{rbST}$ in Friesian bulls improves physical and biochemical characteristics of semen and the fertilizing ability of the treated bulls.

\section{REFERENCES}

Arsenijevic, Y., W.B. Wehrenberg, A. Conz, A. Eshkol, P.C. Sizonenko, N.L. Aubert, 1989. Growth hormon (GH) deprivation induced by passive immuniztion against rat GH-releasing factor delays sexual maturation in the male rat. Endocrinology 124: 3050-3059.

Breier B.H, M.H. Vickers, C.G. Gravance, and P.J. Casey, 1998. Therapy with growth hormone. Major prospects for the treatment of male subfertility. Endocrinology Journal 145 (Supp1.) 553-560.

Carani, C., A.R. Granata, M. DeRosa, C. Garau, S. Zarrilli, L. Paesano, A. Colao, P. Marrwma, and G. Lombard, 1999. The effect of chronic treatment with GH on gonadal function in men with isolated GH deficiency. European. Journal of Endocrinology, 140: 224-230.

Chandrasheker, V. and A. Barttke, 1998. The role of growth hormone in pituitary and testicular function in abult mice. Biology of Reproduction. 38:18.

El-Harairy, M. A. 2000. Ram reproductive performance in response to treatment with somatotropin. Journal of Agriculture Sciences, Mansoura University, 25(7): 39873994.

Hancock, J. L. 1951. A staining technique for the study of temperature shock in semen. Nature London 167: 323.

Hancock, J. L. 1956. The morpholog of boar spermatozoa. Journal of Reproduction Mikrosection Society, $76: 84-97$.

Henault, M. A., G.J. Killian, J.F. Kavanough, and L.C. Jr. Griel, 1995. Effect of accessory sex gland fluid from bulls of differing fertilities on the ability of cauda epididymal sperm to penetrate zona-free bovine oocytes. Biology of Reproduction, 52: 390-397.

Herman, H. A. and F.W. Madden, 1953. The Artificial Insemination of Dairy Cattle. A hand book and laboratory manual. Lucase Brothers Publishers, Colombia, Missori, USA.

Hingnett, P. G. 1957. The general examination of the bull for soundness with special refrence to the assessment of fertility. Veterinary record, $69: 1140-1146$.

Laron, Z. 1984. Type dwarfism, hereditary somatomedin deficiency. A review Advanced International Medical Ped. 51:117-40.

Lee, K. O., P.S. Lee, A.T. Bongso, E.A. Taylor and T.K. Lin, 1995. Effect of growth hormone therapy in men with severe idiopathic oligoazoospermia. European Journal of Endocrinology, 132:159-162.

Mann, T. 1964. The Biochemistry of Semen and Male Reproductive Tract. Methew, London, willey, New York, USA.

National Research Council (NRC), 1988. Nutrient requirements of dairy cattle. $6^{\text {Th }}$ revised edition. National Academy of Science, Washington, DC, USA.

Ovesen, P., Jorgensen, J.O., Ingersiev, J., Ho, K.K., Orskov, H. and Christiansen, J.S. 1996. Growth hormone treatment of subfertile males. Fertility and Sterility, 66: 292-298.

Pareek, P. K., P.N. Roychoudhury and H.C. Gowdan, 1981. Note on the effect of different glycerol level on the release of glutamic oxaloacetic transaminase 
(GOT) from deep frozen spermatozoa. Indian journal of Animal Science, 51:1097-1115

Perry, E. D. 1960. The Artificial Inseminations of Farm Animals. Rutgars University press, 6 edition., New Brunswick, New Jersy, USA.

Radicioni A, E. Paris, F. Dondero and A. Isidori, 1994. Recombinant growth hormone (rec-hGH) therapy in infertil men with idiopathic oligoazoospermia. Acta European Journal of Fertility, 25:311-7.

Reitman, S. and L. Frankel, 1957. Detremination of serum glutamic-oxaloacetic and glutamic pyruvic trans aminase. American Journal of Clinical Pathology, 28 : 56-65

Roussel, J. D. and O.T. Stallcup, 1966. Parallelism between semen characteristics and glutamic oxaloacetic transaminase, glutamic pyruvic transaminase activities. Journal of Dairy Science, 48: 1684-1687

SAS, 1998. SAS user's guide for personal computers, SAS institute Inc., Cary, NC., USA

Sauerwein, H., B.H. Breier, B.W. Gallage, C. Gotz, G. Kufner, T. Montag, M. Vickers and E.S. Challenberger, 2000. Growth hormone treatment of breeding bulls used for artificial insemination improves fertilization rates. Domestic Animal Endocrinology, 18: 1, 145-158.

Schallenberger, E., G. Kufner, T. Montag and W. Lorrmann, 1993. Does bovine somatotropin improve the performance of AI bulls? Tierzuchter. 45: 1, 20-23.

Sptiteri-Grech J. and E. Nieschlag, 1990. The role of growth horme and insulin like growth factor 1 in the regulation of male reprodutive function. Hormonal Research, 38: 22-27.

Zachman, M. 1992. Interrelations between growth hormone and sex hormonesphysiolgy and therapeutic consequence. Hormonal Research, 38:1-8. 


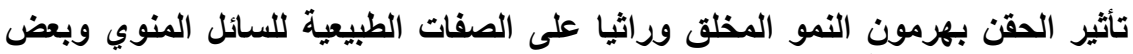

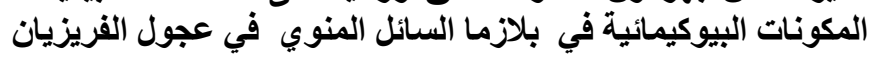

ياسين محمد حافظ1، سهير احمد فوزي، محمود عبد الغنى الحناوى، اشرف هشام برقاوى1 1

1- قسم الإنتاج الحيواني، كلية الزراعة، جامعة القاهرة، 2- معهُ بحوث الإنتاج الحيوانس، وزارة الزراعة، دقي، جيزة، مصر الاتثر

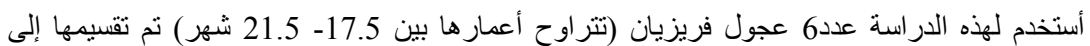

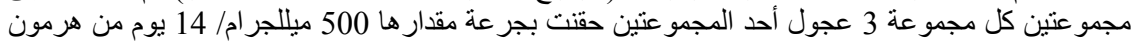

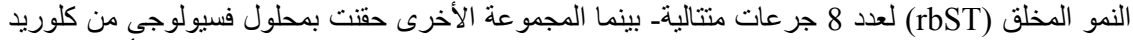

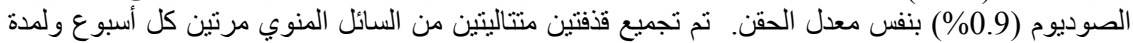

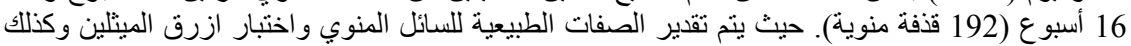
النتائج الحقلية لمعدل الخصوبة لاختبار كفاءة السائل المنوي.

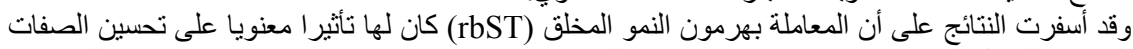

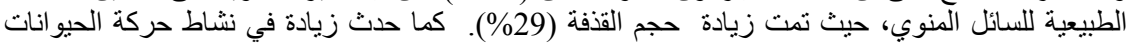

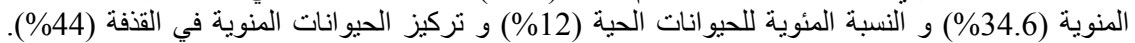

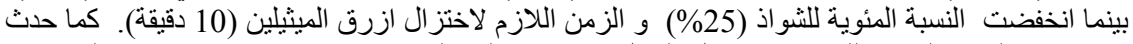

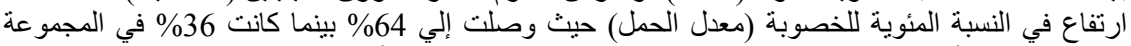

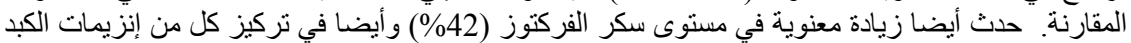

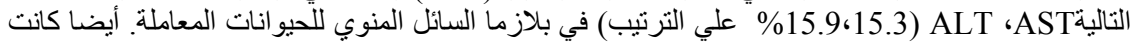

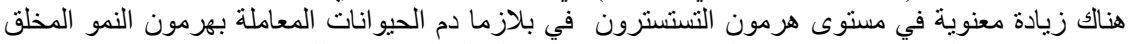

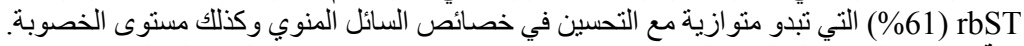
الخلاصة: تثير النتائج الحالية إلي إمكانية الاستفادة من استخدام هرمون النمو المخلق (rbST) في تحسين خصائص السائل المنوي لعجول الفريزيان 